\title{
Model Epidemi Suspected Exposed Infected Recovered (SEIR) Pada Penyebaran COVID-19 Orde-Fraksional
}

\author{
Khoirotun Nisa'*, Hairur Rahman, Ari Kusumastuti \\ Program Studi Matematika, Universitas Islam Negeri Maulana Malik Ibrahim Malang, Indonesia \\ Email: khoirotun241120@gmail.com*, hairur@math.uin-malang.ac.id, arikusumastuti@gmail.com
}

\begin{abstract}
Abstrak
Artikel ini membahas tentang solusi persamaan SEIR orde fraksional dengan bantuan Metode Perturbasi Homotopi (HPM). Model matematika ini merupakan model SEIR dari penyebaran kasus COVID-19 di Indonesia. Pada umumnya solusi Sistem Persamaan Diferensial Biasa (SPDB) taklinier cukup sulit untuk dicari secara analitik, sehingga penelitian ini akan mengubah SPDB taklinier menjadi Sistem Persamaan Diferensial Fraksional (SPDF). Metode yang digunakan dalam menyelesaikan penelitian ini adalah metode MPH (Metode Perturbasi Homotopi). Solusi untuk orde fraksional dengan metode MPH diperoleh dengan langkah-langkah sebagai berikut, 1). Mengalikan setiap persamaan SEIR terhadap parameter embedding (tambahan) dan menyamakan masing-masing koefisien dalam deret tak hingga yang sudah diasumsikan untuk mengetahui solusinya. 2). Menyimulasikan solusi numerik dan melakukan interpretasi grafik. Simulasi numerik menunjukkan bahwa populasi manusia yang rentan, populasi manusia yang terinfeksi tanpa gejala, populasi manusia yang sembuh mengalami kenaikan, berbeda dengan populasi manusia terinfeksi dengan gejala yang mengalami penurunan. Metode MPH dalam solusi numeriknya menunjukkan perbandingan yang cukup kecil terhadap solusi SPDB taklinier.
\end{abstract}

Kata kunci: Penyebaran COVID-19; Orde Fraksional; Metode Perturbasi Homotopi; Parameter Tambahan.

\begin{abstract}
This article discusses the solution to the fractional order SEIR equation with the help of the Homotopy Perturbation Method (HPM). This mathematical model is the SEIR model of the spread of COVID-19 cases in Indonesia. In general, the nonlinear Ordinary Differential Equation System (ODES) solution is quite difficult to solve analytically, so this research will transform the nonlinear ODES into a Fractional Differential Equation System (FDES). The method used in completing this research is the HPM method. The solution for the fractional order by the HPM method is obtained by the following steps: 1). Multiply each SEIR equation against the embedding parameter and equate each coefficient in the assumed infinite series to find the solution, 2). Simulate numerical solutions and perform graph interpretation. The numerical simulation shows that the susceptible human population, the infected human population without symptoms, the recovered human population has increased, in contrast to the infected human population with decreased symptoms. The HPM method in its numerical solution shows a fairly small comparison to the nonlinear ODES solution.
\end{abstract}

Keywords: Spread of COVID-19; Fractional Order; Homotopy Perturbation Method; Additional Parameters.

\section{PENDAHULUAN}

Virus COVID-19 mulai teridentifikasi kode genetiknya dan diumumkan secara resmi oleh WHO pada 10 Januari 2020 [1]. Gejala yang ditimbulkan COVID-19 ini adalah suatu infeksi saluran pernafasan baik dalam ruang lingkup yang ringan maupun berat [2]. Pada tanggal 2 Maret 2020, Indonesia mengalami kasus pertama penyebaran virus ini. Hal ini terjadi diduga adanya warga jepang yang berkunjung ke Indonesia. Penyebaran jumlah kasus COVID-19 di Indonesia pun terus 
bertambah, sampai pada tanggal 11 Februari 2021 tercatat 1.191 .990 kasus terkonfirmasi positif, 993.117 sembuh dan 32.381 meninggal dunia [3].

Hal yang dapat dilakukan untuk mencegah penularan virus COVID-19 yakni lockdown. Di kota Wuhan, setelah melakukan lockdown selama beberapa hari kasus penyebaran ini semakin berkurang. Sehingga lockdown ini menjadi cara yang tepat untuk beberapa negara lain yang terpapar COVID-19 di seluruh dunia [4]. Selain lockdown, langkah yang dapat dilakukan adalah melakukan karantina dan isolasi. Bagi pasien dengan risiko yang tinggi dikarantina rumah sakit sedangkan pasien tanpa gejala dikarantina mandiri di rumah atau pada tempat-tempat yang sudah disediakan oleh pemerintah [2].

Salah satu cara untuk menjelaskan permasalahan dalam dunia nyata adalah dengan memodelkan matematika [5]. Dinamika penyebaran COVID-19 dapat diketahui dan digunakan untuk memprediksi penyebarannya melalui simulasi model matematika penyebaran COVID-19 [6]. Model dasar penyebaran COVID-19 adalah SEIR di mana populasi dibagi menjadi sub populasi Suspected (S), Exposed (E), Infected (I), Recovered (R) seperti yang dilakukan oleh Annas dkk. [7], Ala'raj dkk.[8], Yang dkk.[9], Chinazzi dkk. [10], Wang \& Liu [11], dan Kucharski dkk.[12]. Fokus penelitian ini menggunakan model matematika yang dikonstruksi pada penelitian Annas tahun 2020 [7]. Proses dalam konstruksi model matematika tersebut mempertimbangkan faktor vaksinasi dan isolasi sebagai nilai parameter. Adapun hasil konstruksinya adalah sebagai berikut:

$$
\begin{aligned}
& \frac{d S}{d t}=\mu N-(\alpha I+\mu+v) S \\
& \frac{d E}{d t}=\alpha I S-(\beta+\mu) E \\
& \frac{d I}{d t}=\beta E-\left(\mu_{i}+\delta+\mu\right) I \\
& \frac{d R}{d t}=\delta I+v S-\mu R
\end{aligned}
$$

Fokus penelitian ini adalah untuk mencari solusi model penyebaran COVID-19 yang telah dikonstruksi oleh Annas dkk. [7]. Salah satu metode yang digunakan yaitu dengan mengganti turunan pertama SPDB taklinier terhadap turunan fraksional orde $\alpha$ dengan $0<\alpha \leq 1$. Hal ini telah dilakukan oleh Das dan Gupta [13] pada model matematika Lotka-Volterra untuk penyebaran predator dan mangsa.

Berdasarkan permasalahan tersebut, penelitian ini dimaksudkan untuk mencari solusi persamaan SEIR penyebaran COVID-19 orde fraksional dengan bantuan Metode Perturbasi Homotopi (MPH). Hal ini untuk menerapkan metode lain dalam menyelesaikan solusi persamaan SEIR pada penelitian sebelumnya. Manfaat dari penelitian ini yaitu dapat memprediksi kasus penyebaran COVID-19 dengan mempertimbangkan parameter vaksinasi dan isolasi terhadap model berdasarkan data kumulatif yang ada.

\section{METODE}

\section{Langkah-langkah penelitian}

Adapun langkah-langkah yang digunakan dalam penelitian ini adalah sebagai berikut:

1. Mengubah persamaan diferensial biasa taklinier pada model matematika SEIR penyebaran COVID-19 menjadi persamaan diferensial orde-fraksional.

2. Menerapkan Metode Perturbasi Homotopi (MPH) dalam model matematika SEIR penyebaran COVID-19 orde-fraksional.

a) Menentukan kondisi awal pada persamaan

b) Menyubstitusikan parameter tambahan (embedding) pada persamaan diferensial orde-fraksional

c) Mengasumsikan solusi merupakan bentuk dari sebuah deret pangkat pada $q$ (parameter tambahan)

d) Menyubstitusikan rangkaian deret pangkat di $q$ pada masing-masing persamaan yang telah dihasilkan 
e) Mencari nilai dalam parameter model persamaan SEIR dengan menggunakan turunan Fraksional Caputo

f) Menerapkan definisi Integral Fraksional Riemann-Liouville sebagai pengoperasian dengan setiap hasil pada langkah sebelumnya

g) Menyubstitusikan koefisien terhadap suku-suku yang telah didapatkan pada deret

h) Menyubstitusikan nilai $q=1$ pada deret langkah sebelumnya, untuk menemukan solusi persamaan diferensial orde-fraksional dengan menggunakan Metode Perturbasi Homotopi (MPH)

3. Melakukan simulasi numerik dari model matematika SEIR penyebaran COVID-19 ordefraksional dengan metode MPH berdasarkan data kumulatif kasus COVID-19.

\section{HASIL DAN PEMBAHASAN}

\section{Model SEIR Pada Penyebaran COVID-19}

Berdasarkan model (1) pada penelitian Annas, dkk. (2020) dengan syarat awal $S(0)=\omega$, $E(0)=\tau, I(0)=\pi$, dan $R(0)=\vartheta$, akan ditentukan penyelesaian menggunakan Metode Perturbasi Homotopi (MPH) untuk ditemukan solusi nya dengan definisi Caputo, Integral Fraksional Riemann-Liouville [14].

Sistem persamaan (1) diubah ke dalam orde-fraksional sebagai berikut:

$$
\begin{aligned}
& \frac{d^{\alpha_{1}} S}{d t}=\mu N-(\alpha I+\mu+v) S \\
& \frac{d^{\alpha_{1}} E}{d t}=\alpha I S-(\beta+\mu) E \\
& \frac{d^{\alpha_{1} I}}{d t}=\beta E-\left(\mu_{i}+\delta+\mu\right) I \\
& \frac{d^{\alpha_{1}} R}{d t}=\delta I+v S-\mu R,
\end{aligned}
$$

kemudian mengasumsikan bahwa solusi dari persamaan (1) merupakan suatu deret pangkat dalam $q$ (parameter tambahan) sebagai berikut:

$$
\begin{aligned}
S(t) & =S_{0}+q S_{1}+q^{2} S_{2}+q^{3} S_{3}+\cdots \\
E(t) & =E_{0}+q E_{1}+q^{2} E_{2}+q^{3} E_{3}+\cdots \\
I(t) & =I_{0}+q I_{1}+q^{2} I_{2}+q^{3} I_{3}+\cdots \\
R(t) & =R_{0}+q R_{1}+q^{2} R_{2}+q^{3} R_{3}+\cdots
\end{aligned}
$$

Dengan menyubstitusikan persamaan (3) ke dalam persamaan (2) diperoleh persamaan diferensial fraksional sebagai berikut :

$$
\begin{aligned}
& q^{0}: \frac{d^{\alpha_{1}}}{d t^{\alpha_{1}}} S_{0}=0, \\
& q^{1}: \frac{d^{\alpha_{1}}}{d t^{\alpha_{1}}} S_{1}=\mu N-\alpha I_{0} S_{0}-\mu S_{0}-v S_{0}, \\
& q^{2}: \frac{d^{\alpha_{1}}}{d t^{\alpha_{1}}} S_{2}=-\alpha I_{1} S_{0}-\alpha I_{0} S_{1}-\mu S_{1}-v S_{1}, \\
& q^{3}: \frac{d^{\alpha_{1}}}{d t^{\alpha_{1}}} S_{3}=-\alpha I_{0} S_{2}-\alpha I_{1} S_{1}-\alpha I_{2} S_{0}-\mu S_{2}-v S_{2}, \\
& \quad \vdots \\
& q^{n}: \frac{d^{\alpha_{1}}}{d t^{\alpha_{1}}} S_{n}=-\alpha \sum_{i=0}^{n-1} I_{i} S_{n-1-i}-\mu S_{n-1}-v S_{n-1} ; n \geq 2
\end{aligned}
$$

Hal ini berlaku juga untuk mencari nilai pada persamaan $E, I$, dan $R$. Selanjutnya 
menerapkan definisi Caputo, Integral Fraksional Riemann-Liouville dan sifat turunan fraksional Caputo [14] pada persamaan (4). Sehingga diperoleh :

$$
\begin{aligned}
& S_{0}(t)=\omega \\
& E_{0}(t)=\tau \\
& I_{0}(t)=\pi \\
& R_{0}(t)=\vartheta \\
& S_{1}(t)=\frac{M_{1}}{\Gamma\left(\alpha_{1}+1\right)} t^{\alpha_{1}} \\
& E_{1}(t)=\frac{M_{2}}{\Gamma\left(\alpha_{2}+1\right)} t^{\alpha_{2}} \\
& I_{1}(t)=\frac{M_{3}}{\Gamma\left(\alpha_{3}+1\right)} t^{\alpha_{3}} \\
& R_{1}(t)=\frac{M_{4}}{\Gamma\left(\alpha_{4}+1\right)} t^{\alpha_{4}} \\
& S_{2}(t)=-\frac{\alpha \omega M_{3}}{\Gamma\left(\alpha_{1}+\alpha_{3}+1\right)} t^{\alpha_{1}+\alpha_{3}}-\frac{\alpha \pi M_{1}}{\Gamma\left(2 \alpha_{1}+1\right)} t^{2 \alpha_{1}}-\frac{\mu M_{1}}{\Gamma\left(2 \alpha_{1}+1\right)} t^{2 \alpha_{1}} \\
& -\frac{v M_{1}}{\Gamma\left(2 \alpha_{1}+1\right)} t^{2 \alpha_{1}} \\
& E_{2}(t)=\frac{\alpha \omega M_{3}}{\Gamma\left(\alpha_{2}+\alpha_{3}+1\right)} t^{\alpha_{2}+\alpha_{3}}+\frac{\alpha \pi M_{1}}{\Gamma\left(\alpha_{1}+\alpha_{2}+1\right)} t^{\alpha_{1}+\alpha_{2}}-\frac{\beta M_{2}}{\Gamma\left(2 \alpha_{2}+1\right)} t^{2 \alpha_{2}} \\
& -\frac{\mu M_{2}}{\Gamma\left(2 \alpha_{2}+1\right)} t^{2 \alpha_{2}} \\
& I_{2}(t)=\frac{\beta M_{2}}{\Gamma\left(\alpha_{2}+\alpha_{3}+1\right)} t^{\alpha_{2}+\alpha_{3}}-\frac{\mu_{i} M_{3}}{\Gamma\left(2 \alpha_{3}+1\right)} t^{2 \alpha_{3}}-\frac{\delta M_{3}}{\Gamma\left(2 \alpha_{3}+1\right)} t^{2 \alpha_{3}} \\
& -\frac{\mu M_{3}}{\Gamma\left(2 \alpha_{3}+1\right)} t^{2 \alpha_{3}} \\
& R_{2}(t)=\frac{\delta M_{3}}{\Gamma\left(\alpha_{3}+\alpha_{4}+1\right)} t^{\alpha_{3}+\alpha_{4}}+\frac{v M_{1}}{\Gamma\left(\alpha_{1}+\alpha_{4}+1\right)} t^{\alpha_{1}+\alpha_{4}}-\frac{\mu M_{4}}{\Gamma\left(2 \alpha_{4}+1\right)} 2 t^{\alpha_{4}} \\
& S_{3}(t)=\frac{\alpha^{2} \pi \omega M_{3}}{\Gamma\left(2 \alpha_{1}+\alpha_{3}+1\right)} t^{2 \alpha_{1}+\alpha_{3}}+\frac{\alpha \pi(\alpha \pi+\mu+v) M_{1}}{\Gamma\left(3 \alpha_{1}+1\right)} t^{3 \alpha_{1}} \\
& -\frac{\alpha M_{1} M_{3}}{\Gamma\left(\alpha_{3}+1\right) \Gamma\left(\alpha_{1}+1\right)} \frac{\Gamma\left(\alpha_{1}+\alpha_{3}+1\right)}{\Gamma\left(2 \alpha_{1}+\alpha_{3}+1\right)} t^{2 \alpha_{1}+\alpha_{3}} \\
& -\frac{\alpha \omega \beta M_{2}}{\Gamma\left(\alpha_{1}+\alpha_{2}+\alpha_{3}+1\right)} t^{\alpha_{1}+\alpha_{2}+\alpha_{3}}+\frac{\left(\mu_{i}+\delta+\mu\right) M_{3}}{\Gamma\left(\alpha_{1}+2 \alpha_{3}+1\right)} t^{\alpha_{1}+2 \alpha_{3}} \\
& +\frac{\mu \alpha \omega M_{3}}{\Gamma\left(2 \alpha_{1}+\alpha_{3}+1\right)} t^{2 \alpha_{1}+\alpha_{3}}+\frac{\mu(\alpha \pi+\mu+v) M_{1}}{\Gamma\left(3 \alpha_{1}+1\right)} t^{3 \alpha_{1}} \\
& +\frac{v(\alpha \pi+\mu+v) M_{1}}{\Gamma\left(3 \alpha_{1}+1\right)} t^{3 \alpha_{1}} \\
& E_{3}(t)=-\frac{\pi \alpha^{2} \omega M_{3}}{\Gamma\left(\alpha_{1}+\alpha_{2}+\alpha_{3}+1\right)} t^{\alpha_{1}+\alpha_{2}+\alpha_{3}}-\frac{\alpha \pi(\alpha \pi+\mu+v) M_{1}}{\Gamma\left(2 \alpha_{1}+\alpha_{2}+1\right)} t^{2 \alpha_{1}+\alpha_{2}} \\
& +\frac{\alpha M_{1} M_{3}}{\Gamma\left(\alpha_{3}+1\right) \Gamma\left(\alpha_{1}+1\right)} \frac{\Gamma\left(\alpha_{1}+\alpha_{3}+1\right)}{\Gamma\left(\alpha_{1}+\alpha_{2}+\alpha_{3}+1\right)} t^{\alpha_{1}+\alpha_{2}+\alpha_{3}} \\
& +\frac{\alpha \omega \beta M_{2}}{\Gamma\left(2 \alpha_{2}+\alpha_{3}+1\right)} t^{2 \alpha_{2}+\alpha_{3}}-\frac{\left(\mu_{i}+\delta+\mu\right) M_{3}}{\Gamma\left(\alpha_{2}+2 \alpha_{3}+1\right)} t^{\alpha_{2}+2 \alpha_{3}} \\
& -\frac{\beta \alpha \omega M_{3}}{\Gamma\left(2 \alpha_{2}+\alpha_{3}+1\right)} t^{2 \alpha_{2}+\alpha_{3}}-\frac{\beta \alpha \pi M_{1}}{\Gamma\left(\alpha_{1}+2 \alpha_{2}+1\right)} t^{\alpha_{1}+2 \alpha_{2}} \\
& +\frac{\beta(\beta+\mu) M_{2}}{\Gamma\left(3 \alpha_{2}+1\right)} t^{3 \alpha_{2}}-\frac{\mu \alpha \omega M_{3}}{\Gamma\left(2 \alpha_{2}+\alpha_{3}+1\right)} t^{2 \alpha_{2}+\alpha_{3}} \\
& -\frac{\mu \alpha \pi M_{1}}{\Gamma\left(\alpha_{1}+2 \alpha_{2}+1\right)} t^{\alpha_{1}+2 \alpha_{2}}+\frac{\mu(\beta+\mu) M_{2}}{\Gamma\left(3 \alpha_{2}+1\right)} t^{3 \alpha_{2}}
\end{aligned}
$$




$$
\begin{aligned}
& I_{3}(t)=\frac{\beta \alpha \omega M_{3}}{\Gamma\left(\alpha_{2}+2 \alpha_{3}+1\right)} t^{\alpha_{2}+2 \alpha_{3}}+\frac{\beta \alpha \pi M_{1}}{\Gamma\left(\alpha_{1}+\alpha_{2}+\alpha_{3}+1\right)} t^{\alpha_{1}+\alpha_{2}+\alpha_{3}} \\
& -\frac{\beta(\beta+\mu) M_{2}}{\Gamma\left(2 \alpha_{2}+\alpha_{3}+1\right)} t^{2 \alpha_{2}+\alpha_{3}}-\frac{\mu_{i} \beta M_{2}}{\Gamma\left(\alpha_{2}+2 \alpha_{3}+1\right)} t^{\alpha_{2}+2 \alpha_{3}} \\
& +\frac{\mu_{i}\left(\mu_{i}+\delta+\mu\right) M_{3}}{\Gamma\left(3 \alpha_{3}+1\right)} t^{3 \alpha_{3}}-\frac{\delta \beta M_{2}}{\Gamma\left(\alpha_{2}+2 \alpha_{3}+1\right)} t^{\alpha_{2}+2 \alpha_{3}} \\
& +\frac{\delta\left(\mu_{i}+\delta+\mu\right) M_{3}}{\Gamma\left(3 \alpha_{3}+1\right)} t^{3 \alpha_{3}}-\frac{\mu \beta M_{2}}{\Gamma\left(\alpha_{2}+2 \alpha_{3}+1\right)} t^{\alpha_{2}+2 \alpha_{3}} \\
& +\frac{\mu\left(\mu_{i}+\delta+\mu\right) M_{3}}{\Gamma\left(3 \alpha_{3}+1\right)} t^{3 \alpha_{3}} \\
& R_{3}(t)=\frac{\delta \beta M_{2}}{\Gamma\left(\alpha_{2}+\alpha_{3}+\alpha_{4}+1\right)} t^{\alpha_{2}+\alpha_{3}+\alpha_{4}}-\frac{\delta\left(\mu_{i}+\delta+\mu\right) M_{3}}{\Gamma\left(2 \alpha_{3}+\alpha_{4}+1\right)} t^{2 \alpha_{3}+\alpha_{4}} \\
& -\frac{v \alpha \omega M_{3}}{\Gamma\left(\alpha_{1}+\alpha_{3}+\alpha_{4}+1\right)} t^{\alpha_{1}+\alpha_{3}+\alpha_{4}}-\frac{v(\alpha \pi+\mu+v) M_{1}}{\Gamma\left(2 \alpha_{1}+\alpha_{4}+1\right)} t^{2 \alpha_{1}+\alpha_{4}} \\
& -\frac{\mu \delta M_{3}}{\Gamma\left(\alpha_{3}+2 \alpha_{4}+1\right)} t^{\alpha_{3}+2 \alpha_{4}}-\frac{\mu v M_{1}}{\Gamma\left(\alpha_{1}+2 \alpha_{4}+1\right)} t^{\alpha_{1}+2 \alpha_{4}} \\
& +\frac{\mu^{2} M_{4}}{\Gamma\left(3 \alpha_{4}+1\right)} 3 t^{\alpha_{4}}
\end{aligned}
$$

Dengan demikian solusi dari persamaan (1) adalah sebagai berikut:

$$
\begin{aligned}
S(t) & =S_{0}+S_{1}+S_{2}+S_{3}+\cdots \\
E(t) & =E_{0}+E_{1}+E_{2}+E_{3}+\cdots \\
I(t) & =I_{0}+I_{1}+I_{2}+I_{3}+\cdots \\
R(t) & =R_{0}+R_{1}+R_{2}+R_{3}+\cdots
\end{aligned}
$$

\section{Simulasi Grafik}

Simulasi grafik untuk solusi numerik pada persamaan SEIR penyebaran COVID-19 yaitu dengan bantuan perangkat lunak MATLAB. Berikut nilai-nilai parameter yang akan digunakan berdasarkan data kumulatif kasus COVID-19 di Jawa Timur tahun 2020:

Tabel 1 Nilai awal untuk model SEIR penyebaran COVID-19 di Jawa Timur

\begin{tabular}{cccc}
\hline Variabel & Nilai & Keterangan & Sumber \\
\hline$S(0)$ & 84.152 Orang & $\begin{array}{c}\text { Jumlah populasi } \\
\text { manusia rentan } \\
\text { COVID-19 }\end{array}$ & {$[15]$} \\
$E(0)$ & 46.185 Orang & $\begin{array}{c}\text { Jumlah populasi } \\
\text { manusia rentan } \\
\text { COVID-19 / sakit } \\
\text { tidak dikatakan } \\
\text { COVID-19 }\end{array}$ & {$[15]$} \\
$I(0)$ & 37.967 Orang & $\begin{array}{c}\text { Jumlah populasi } \\
\text { manuisia terkena } \\
\text { COVID-19 } \\
\text { Jumlah populasi } \\
\text { manusia sembuh } \\
\text { dari CoVID-19 } \\
\text { Jumlah penduduk } \\
\text { Jawa Timur pada } \\
\text { desember 2020 }\end{array}$ & {$[15]$} \\
\hline
\end{tabular}


Tabel 2 Nilai parameter untuk model SEIR penyebaran COVID-19 di Jawa Timur

\begin{tabular}{cccc}
\hline Parameter & Nilai & Keterangan & Sumber \\
\hline$B$ & 0.0079 & Laju kelahiran manusia & {$[16]$} \\
$\mu$ & 0.0010243 & Laju kematian alami manusia & {$[16]$} \\
$\mu_{i}$ & 0.0000007344 & $\begin{array}{c}\text { Laju kematian manusia karena } \\
\text { COVID-19 }\end{array}$ & {$[7]$} \\
$\alpha$ & 0.0000000062 & $\begin{array}{c}\text { Kemungkinan perubahan dari } S \text { ke } \\
E\end{array}$ & {$[7]$} \\
$\beta$ & 0.00115 & Kemungkinan perubahan dari $E$ ke & {$[7]$} \\
& & $I$ & \\
$\delta$ & 0.0006667 & Kemungkinan perubahan dari $I$ ke & {$[7]$} \\
& & $R$ & \\
$v$ & 0.05 & Laju vaksin & {$[7]$} \\
\hline
\end{tabular}

Sebelum melakukan pendekatan simulasi numerik untuk kasus di Jawa Timur, akan dilakukan perbandingan simulasi numerik dari pendekatan solusi persamaan SEIR dengan menggunakan ODE45 terhadap solusi persamaan SEIR dengan menggunakan metode MPH dengan orde $\alpha_{1}=\alpha_{2}=\alpha_{3}=\alpha_{4}=1$. Sehingga menghasilkan output grafik sebagai berikut:

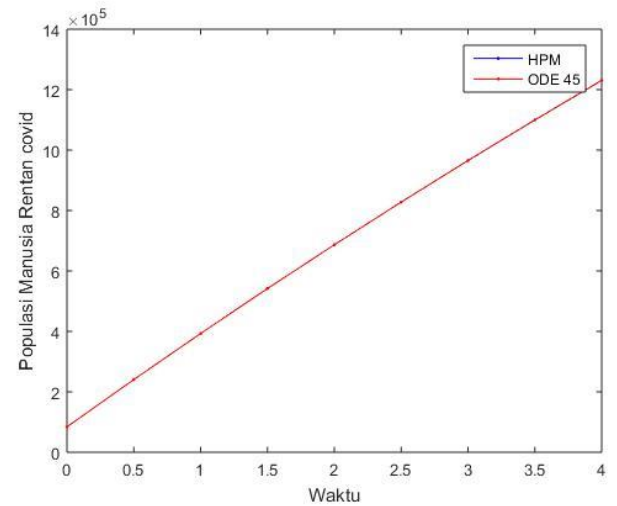

Gambar a

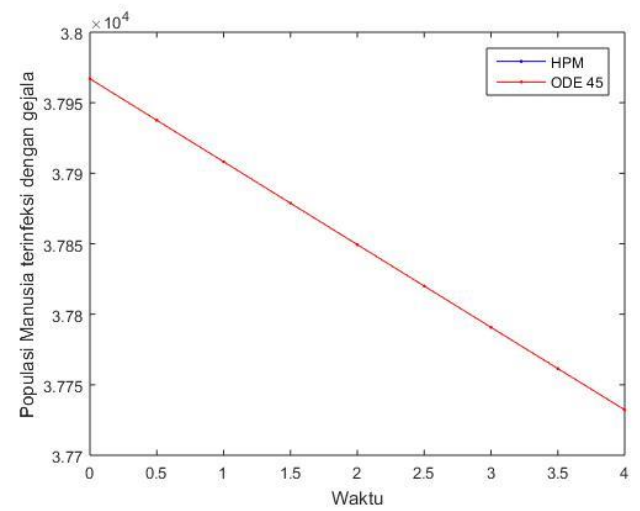

Gambar c

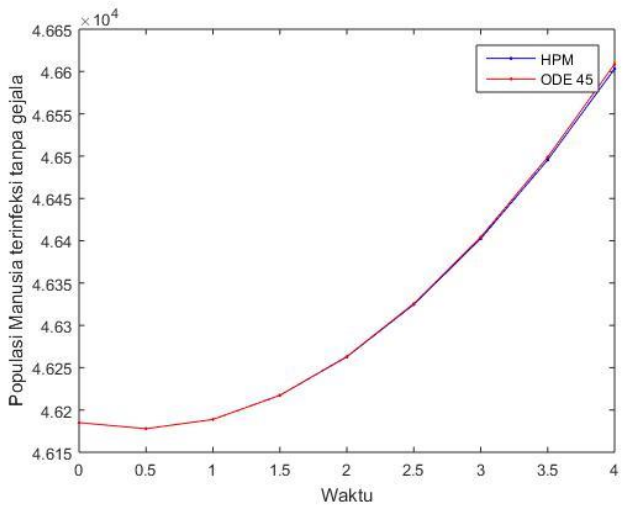

Gambar b

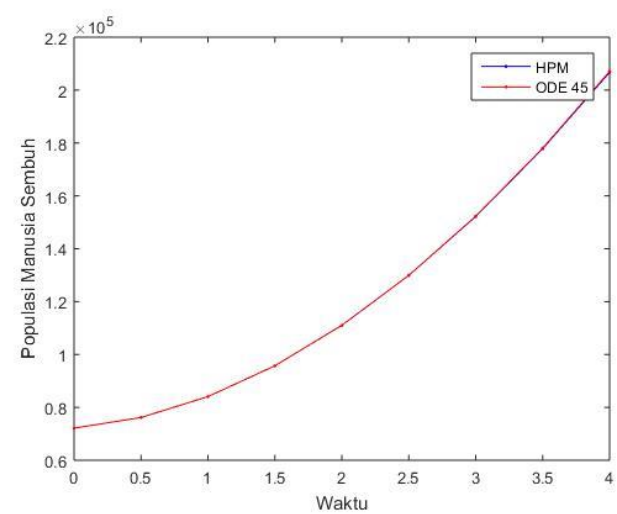

Gambar d

Gambar 3.1 Perbandingan simulasi numerik SPDB taklinier dengan SPDF pada $\alpha_{1}=\alpha_{2}=\alpha_{3}=\alpha_{4}=1$

Berdasarkan Gambar 3.1, terlihat bahwa populasi manusia yang rentan terinfeksi virus COVID-19 mengalami kenaikan dari waktu ke waktu (gambar a) begitu pula dengan kenaikan populasi manusia yang terinfeksi virus tanpa menunjukkan gejala (gambar b) yang berbanding 
terbalik dengan penurunan populasi manusia yang terinfeksi dengan gejala (gambar c) serta populasi manusia yang sembuh dari COVID-19 mengalami peningkatan (gambar d). Hal ini dikarenakan laju populasi manusia yang sembuh dari COVID-19 lebih besar daripada laju populasi manusia yang terinfeksi virus sehingga menyebabkan populasi manusia yang terinfeksi mengalami penurunan. Selain itu, terlihat juga bahwa perbedaan pola pada simulasi numerik dari solusi SPDB taklinier dengan solusi menggunakan MPH kecil, sehingga dapat disimpulkan bahwa SPDB taklinier dapat diselesaikan dengan menggunakan metode MPH.

Selanjutnya simulasi numerik yang digunakan adalah simulasi dari solusi dengan menggunakan MPH dan akan dilihat pengaruh dari $\alpha_{1}, \alpha_{2}, \alpha_{3}$, dan $\alpha_{4}$ terhadap dinamika populasi manusia di Jawa Timur, Indonesia. Pada kasus di Jawa Timur, nilai parameter yang digunakan pada tabel 3.1. Untuk mengetahui pengaruh dari $\alpha_{1}$ maka akan dilakukan pendekatan simulasi numerik dengan nilai $\alpha_{1}=1, \alpha_{1}=0.75, \alpha_{1}=0.5, \alpha_{1}=0.25$ sementara nilai $\alpha_{2}=\alpha_{3}=\alpha_{4}=$ $\alpha_{5}=1$. Berikut hasil simulasi tersebut.
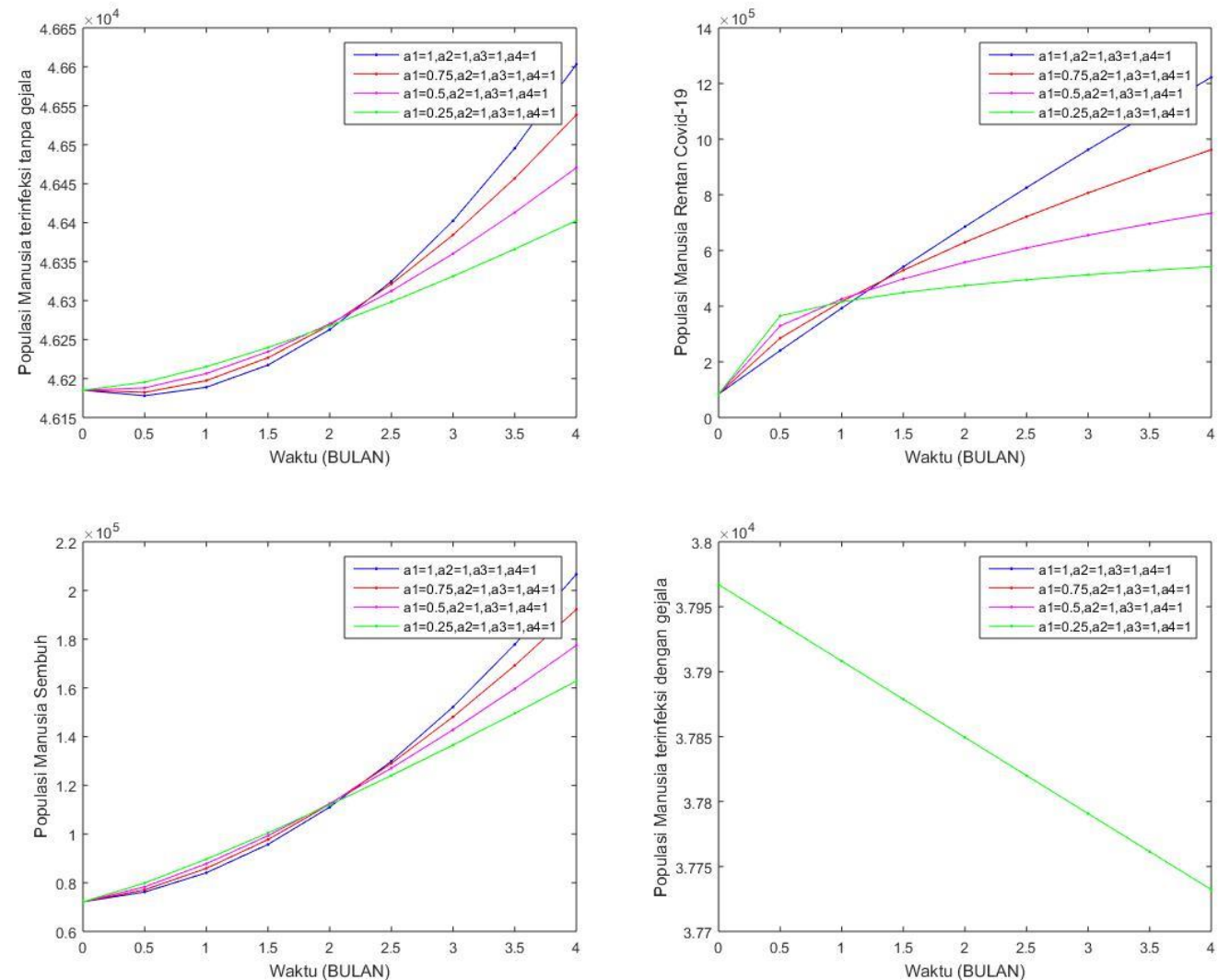

Gambar 3.2 Pengaruh $\alpha_{1}$ terhadap dinamika populasi manusia

Dari gambar 3.2 dapat dilihat bahwa nilai $\alpha_{1}$ berpengaruh cukup besar terhadap populasi manusia yang rentan terinfeksi virus COVID-19, populasi manusia yang terinfeksi tanpa gejala, dan populasi manusia yang sembuh dari COVID-19. Semakin besar nilai $\alpha_{1}$ maka perubahan gerafiknya semakin cepat. Sebaliknya semakin kecil nilai $\alpha_{1}$ maka perubahan grafiknya semakin lambat.

\section{KESIMPULAN} berikut:

Dari hasil pembahasan pada bab sebelumnya, dapat ditarik kesimpulan yaitu sebagai

1. Solusi penyelesaian dari SPDF model matematika penyebaran penyakit COVID-19 dengan menggunakan Metode Perturbasi Homotopi (MPH) adalah : 


$$
\begin{aligned}
S(t) & =S_{0}+S_{1}+S_{2}+S_{3}+\cdots \\
E(t) & =E_{0}+E_{1}+E_{2}+E_{3}+\cdots \\
I(t) & =I_{0}+I_{1}+I_{2}+I_{3}+\cdots \\
R(t) & =R_{0}+R_{1}+R_{2}+R_{3}+\cdots
\end{aligned}
$$

Berdasarkan hasil simulasi numerik menggunakan MATLAB terlihat bahwa populasi manusia yang rentan mengalami kenaikan dari waktu ke waktu, begitu pula dengan kenaikan populasi manusia yang terinfeksi tanpa gejala yang berbanding terbalik dengan penurunan populasi manusia yang terinfeksi bergejala serta populasi manusia yang sembuh mengalami peningkatan. Selain itu terlihat juga, bahwa perbedaan pola pada simulasi numerik dari solusi SPDB taklinier dengan solusi menggunakan MPH kecil, sehingga dapat disimpulkan bahwa SPDB taklinier dapat diselesaikan dengan menggunakan metode MPH. Di mana pengaruh setiap orde $\alpha$ terhadap persamaan SEIR cukup besar pengaruhnya.

\section{DAFTAR PUSTAKA}

[1] R. Ghanam, E. L. Boone, and A.-S. G. Abdel-Salam, "SEIRD MODEL FOR QATAR COVID-19 OUTBREAK : A 1 Introduction 2 The SEIRD Model," Lett. Biomath. - An Int. J., vol. 0, no.0, pp. 1-11, 2020.

[2] Mustika, Syifa. 2020. The New Normal Life. Malang: Satgas Peduli Covid-19 NU.

[3] Komite Pengendalian Covid-19 dan Pemulihan Ekonomi Nasional (KPC PEN), "Peta Sebaran COVID-19." https://covid19.go.id/peta-sebaran-covid19.(accessed Feb. 11, 2021).

[4] M. Ali, S. T. H. Shah, M. Imran, and A. Khan, "The role of asymptomatic class, quarantine and isolation in the transmission of COVID-19," Journal of Biological Dynamics, vol. 14, no. 1. pp. 389-408, 2020, doi: 10.1080/17513758.2020.1773000.

[5] I. Taufiq and D. Agustito, "Application of Mathematical Models Two Predators and Infected Prey by Pesticide Control in Nilaparvata Lugens Spreading in Bantul Regency," Inpr. Indones. J. Pure Appl. Math., vol. 2, no. 1, pp. 41-50, 2020, doi: 10.15408/inprime.v2i1.14887.

[6] N. Inayah, M. Manaqib, N. Fitriyati, and I. Yupinto, "Model Matematika Dari Penyebaran Penyakit Pulmonary Tuberculosis Dengan Penggunaan Masker Medis," BAREKENG J. Ilmu Mat. dan Terap., vol. 14, no. 3, pp. 461-472, 2020, doi: 10.30598/barekengvol14iss3pp461-472.

[7] Annas, Suwardi, \& dkk. 2020. Stability analysis and numerical simulation of SEIR model for pandemic COVID-19 spread in Indonesia. Journal of Elsevier, vol 130.

[8] M. Ala'raj, M. Majdalawieh, and N. Nizamuddin, "Modeling and forecasting of COVID-19 using a hybrid dynamic model based on SEIRD with ARIMA corrections," Infect. Dis. Model., vol. 6, pp. 98-111, 2021, doi: 10.1016/j.idm.2020.11.007.

[9] Z. Yang et al., "Modified SEIR and AI prediction of the epidemics trend of COVID-19 in China under public health interventions," J. Thorac. Dis., vol. 12, no. 3, pp. 165-174, 2020, doi: $10.21037 /$ jtd.2020.02.64

[10] M. Chinazzi et al., "The effect of travel restrictions on the spread of the 2019 novel coronavirus (2019-nCoV) outbreak," medRxiv, vol. 9757, no. March, pp. 1-12, 2020, doi: 10.1101/2020.02.09.20021261.

[11] C. Wang et al., "Evolving epidemiology and impact of non-pharmaceutical interventions on the outbreak of coronavirus disease 2019 in Wuhan, China," medRxiv, 2020, doi: 10.1101/2020.03.03.20030593.

[12] A. J. Kucharski et al., "Early dynamics of transmission and control of COVID-19: A mathematical modelling study," medRxiv. 2020, doi: 10.1101/2020.01.31.20019901.

[13] Das, S. dan Gupta, P.K. 2011. A Mathematical Model on Fractional Lotka Voltera Equations, In Journal of Theoretical Biology, vol 277 page 1-6. 
[14] Hemeda, A. A. 2012. Metode Pertubas Homotopi for Solving Partial Differential Equations of Fractional Order. In Journal of Math, Analysis, vol 6 page 2431 - 2448.

[15] Infocovid, 2020. Peta Sebaran COVID-19 Jawa Timur, Availablefrom: https://infocovid19.jatimprov.go.id/ (Accesed 25 Agustus 2021).

[16] Badan Pusat Statistik Jawa Timur, 2020. Pertumbuhan dan Kematian Penduduk Jawa Timur 2020. Surabaya : Badan Pusat Statistik 